"Volume 10, No. 2, Desember 2016"

\title{
REFORMULASI PEMANFAATAN BARANG GADAI PERSPEKTIF HUKUM ISLAM
}

\author{
Oleh: \\ Abdul Wasik \& Imam Fawaid \\ Fakultas Syari'ah STAI At-Taqwa Bondowoso \\ Fakultas Syari'ah IAI Ibrahimy Situbondo \\ abdul_wasik80@yahoo.co.id \& fawaidmyel@gmail.com
}

\begin{abstract}
Pawnshop's motto is to solve the problem without any problems that should be upheld as a form of social interaction in the field of Muamalah.But the reality in the society,mortgageis at issue by priests of Islamic sects because that is opposed the concept of Islam that has been previously codified. On the other hand, some scholars of Islam say that Mortgagor(Murtahin)have no right to exploit and use thegoodsthat pawned, and on the other handthere is the process of massive poverty in the society, especially forPledgor (Rohin). Therefore, the middle ground in this issue is the changing mindset of the public in understanding the meaning and the purpose ofmortgage and reformulate that utilization in accordance with Islamic law.
\end{abstract}

Keywords: Gadai Dan Reformulasi Pemanfataan Barang Gadai

\section{A. Pendahuluan}

Manusia adalah makhluk sosial, yaitu makhluk yang berkodrat hidup dalam masyarakat. Sebagai makhluk sosial, dalam hidupnya manusia memerlukan adanya manusia-manusia lain yang bersama-sama hidup dalam masyarakat. Dalam hidup bermasyarakat, manusia selalu berhubungan satu sama lain, disadari atau tidak untuk mencukupkan kebutuhan-kebutuhan hidupnya. Pergaulan hidup tempat setiap orang melakukan perbuatan dalam hubungannya dengan orang lain disebut muamalah. ${ }^{1}$ Dan dalam konteks Legeslasi Hukum Islam dinamakan Fiqh Muamalah. $^{2}$

1 Ahmad Azhar Basyir, Asas-asas Hukum Muamalah (Hukum Perdata Islam), ed. Revisi, (Yogyakarta: UII Press, 2000), hlm. 11.

2 Pembagian fiqh yang pupuler adalah: 1). Hukum yang berkaitan dengan penghambaan kepada Allah, hukum ini dinamakan figh ibadah, 2). Hukum yang berkaitan dengan keluarga, seperti nikah, nasab, perceraian dan lain sebagainya dinamakan hukum Ahwal Asy-Syahsiyah, 3). Hukum yang berkaitan dengan pergaulan manusia dalam perkara harta, hak dan penyelesaian urusan tersebut, hukum ini dinamakan fiqh 
Masalah muamalah selalu dan terus berkembang, tetapi perlu diperhatikan agar perkembangan tersebut tidak menimbulkan kesulitankesulitan hidup pada pihak tertentu yang disebabkan oleh adanya tekanan-tekanan atau tipuan dari pihak lain.

Islam adalah agama yang memberi pedoman hidup kepada manusia secara menyeluruh, meliputi segala aspek kehidupannya mencakup aspek-aspek aqidah, ibadah, akhlak dan kehidupan bermasyarakat menuju tercapainya kebahagiaan hidup rohani dan jasmani, baik dalam kehidupan individunya, maupun dalam kehidupan masyarakatnya. ${ }^{3}$

Agama Islam mengajarkan kepada umatnya supaya hidup saling tolong-menolong, yang kaya harus menolong yang miskin, yang mampu harus menolong yang kurang mampu. Bentuk dari tolongmenolong ini bisa berupa pemberian dan bisa juga berupa pinjaman.

Dalam bentuk pinjaman, hukum Islam menjaga kepentingan kreditur, jangan sampai ia dirugikan. Oleh sebab itu, ia dibolehkan meminta barang dari debitur sebagai jaminan utangnya. Sehingga apabila debitur itu tidak mampu melunasi pinjamannya, maka barang jaminan boleh dijual oleh kreditur.

Konsep tersebut dalam fiqh Islam dikenal dengan istilah rahn atau gadai. ${ }^{4}$ Salah satu bentuk perwujudan dari muamalah yang disyari'atkan oleh Allah adalah gadai berdasarkan firman Allah SWT yang berbunyi: ${ }^{5}$

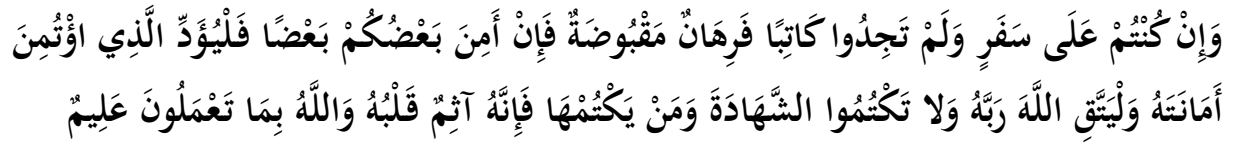
" Jika kamu dalam perjalanan (dan bermuamalah tidak secara tunai) sedang kamu tidak memperoleh seorang penulis, maka hendaklah ada

muamalah, 4). Hukum yang berkaitan dengan otoritas kehakiman, dinamakan Fiqh AlAhkam Al-Sulthoniyah, 5). Hukum yang berkaitan dengan sanksi hokum bagi pelaku tindak criminal, dinamakan fiqh al-uqubat, 6). Hukum yang berkaitan dengan upaya penertiban hubungan antara pemerintah islam, dinamakan fiqh al-huquq al-dauliyah, dan 7). Hukum yang berkaitan dengan akhlaq/ etika, yang dinamakan Al-'Adab. Musthofa AlZarqo', Al-Madkhol Al-Fiqh Al-'Am, (Bairut; Dar Al-Fikr, tt), hlm. 55.

3 Suparman Usman, Hukum Islam (Asas-asas Dan Pengantar Studi Hukum Islam Dalam Tata Hukum Indonesia), (Jakarta: Gaya Media Pratama, 2001), hlm. 66. hlm. 1-3

${ }^{4}$ Muhammad Solikhul Hadi, Pegadaian Syariah, (Jakarta: Salemba Diniyah, 2003)

${ }^{5}$ Al-Baqarah (2): 283

314 JURNAL LISAN AL-HAL 
barang tanggungan yang dibuat/dipegang (oleh yang berpiutang). Akan tetapi jika sebagian kamu mempercayai sebagian yang lain, maka hendaklah yang dipercayai itu menunaikan amanatnya (utangnya) dan hendaklah ia bertakwa kepada Allah Tuhannya; dan janganlah kamu (para saksi) menyembunyikan persaksian. Dan barang siapa yang menyembunyikannya, maka sesungguhnya ia adalah orang yang berdosa hatinya; dan Allah Maha mengetahui apa yang kamu kerjakan"

Dari ayat di atas dapat diketahui bahwa Allah memerintahkan kepada pihak-pihak yang mengadakan perjanjian saat dalam perjalanan tetapi tidak mampu menyediakan seseorang yang bertugas mencatat perjanjian tersebut, untuk memperkuat adanya perjanjian, pihak yang berhutang harus menyerahkan barang gadai kepada pihak yang menghutangi. Ini dilakukan agar mampu menjaga ketenangan hatinya, sehingga tidak mengkhawatirkan atas uang yang diserahkan kepada rahin.

Gadai merupakan salah satu kategori dari perjanjian utang piutang untuk suatu kepercayaan dari orang yang berpiutang, maka orang yang berutang menggadaikan barangnya sebagai jaminan/agunan terhadap utangnya itu. Barang jaminan tetap menjadi milik orang yang menggadaikan (orang yang berutang/debitur) tetapi dikuasi oleh penerima gadai (yang berpiutang/kreditur). Praktek seperti ini telah ada sejak zaman Rasulullah SAW, dan beliau sendiri pun pernah melakukannnya, sebagaimana yang diterangkan dalam hadits di bawah ini:

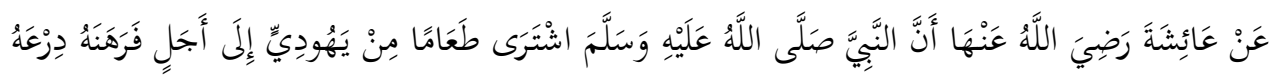

"Dari Aisyah RA, sesungguhnya Nabi Muhammad SAW membeli makan dari seorang yahudi dengan cara berutang maka beliau menggadaikan baju besinya". ${ }^{6}$

Dalam masalah gadai, Islam telah mengaturnya seperti yang telah diungkapkan oleh ulama fiqh, baik mengenai rukun, syarat, dasar hukum maupun tentang pemanfaatan barang gadai oleh penerima gadai yang semua itu bisa dijumpai dalam kitab-kitab fiqh. Dalam pelaksanaannya tidak menutup kemungkinan adanya penyimpangan dari aturan yang ada, terlebih lagi ketika barang jaminan tersebut berupa tanah sawah.

Pemanfaatan tanah sawah oleh si penerima gadai ini yang kemudian

${ }^{6}$ Imam al-Bukhāri, Sahih al-Bukhāri, (Beirut: Dār al-Fikr, 1891), III : 1115, " Bab Fī Rahni Fī al-HadĪs". Hadits riwayat al-Bukhāri dari Musaddad dari ab al-Wahid dari alA'mas dari Ibrahim. 
menjadi masalah krusial yang mendorong penulis untuk melakukan pengkajian ulang terkait permasalahan tersebut secara mendalam. Karena praktek gadai seperti ini cendrung merugikan si pemilik sawah dan menimbulkan gejala-gejala sosial yang dapat merusak tatanan masyarakat desa yang notabene-nya menjadikan tanah sawah sebagai mata pencaharian pertama dan utama bahkan satu-satunya. Lebih-lebih dapat menjadikan pemiskinan secara massif yang pada akhirnya akan meningkatkan jumlah angka pengangguran dan semakin memperdalam jurang antara beberapa orang kaya disatu sisi dan banyak masyarakat miskin di sisi yang lain.

\section{B. Pembahasan}

\section{Tinjauan Gadai Dalam perspektif Hukum Islam (Syariah)}

Pertama, Pengertian Gadai menurut Hukum Islam (Syariah). Transaksi hukum gadai dalam fikih Islam disebut rahn. Rahn adalah suatu jenis perjanjian untuk menahan suatu barang sebagai tanggungan hutang. Pengertian rahn dalam bahasa Arab adalah ats-tsubut dan addawam yang berarti "tetap" dan "kekal", seperti pada kalimat ma-un rahinun, yang berarti air yang tenang. Hal itu, berdasarkan firman Allah SWT dalam QS. Al-Muddatstsir (74) ayat 38: "Setiap orang bertanggung jawab atas apa yang telah diperbuatnya".

Pengertian "tetap" dan "kekal" dimaksud, merupakan makna yang tercakup dalam kata al-habsu, yang berarti menahan. Kata ini merupakan makna yang bersifat materiil. Karena itu, secara bahasa kata Ar-Rahn berarti "menjadikan sesuatu barang yang bersifat materi sebagai pengikat hutang.

Pengertian gadai (Rahn) dalam Hukum Islam (Syara') adalah menjadikan suatu barang yang mempunyai nilai harta dalam pandangan syara' sebagai jaminan hutang, yang memungkinkan untuk mengambil seluruh atau sebagian hutang dari barang tersebut. ${ }^{7}$

Gadai menurut Hukum Islam (Syariah) atau dalam penelitian ini lebih lanjut disebut dengan Gadai Syariah (rahn) adalah menahan salah satu harta milik nasabah (rahin) sebagai barang jaminan (marhun) atas hutang/pinjaman (marhun bih) yang diterimanya. Marhun tersebut memiliki nilai ekonomis. Dengan demikian, pihak yang menahan atau penerima gadai (murtahin) memperoleh jaminan untuk dapat mengambil kembali seluruh atau sebagian piutangnya. ${ }^{8}$

${ }^{7}$ Zainuddin Ali. Hukum Gadai Syariah. (Jakarta: Sinar Grafika. 2008). hlm: 2

8 Muhammad Syafi'i Antonio. Bank Syariah dai Teori ke Praktik. (Jakarta: Gema 
Berdasarkan uraian diatas dapat disimpulkan bahwa gadai syariah merupakan perjanjian antara seseorang untuk menyerahkan harta benda berupa emas / perhiasan / kendaraan dan / atau harta benda lainnya sebagai jaminan dan/atau agunan kepada seseorang dan/atau lembaga gadai syariah berdasarkan hukum gadai syariah. Fungsi akad perjanjian dalam pengertian gadai ( $r a h n$ ) antara pihak peminjam dengan pihak yang meminjam uang adalah untuk memberikan ketenangan bagi pemilik uang dan/atau jaminan keamanan uang yang dipinjamkan. Karena itu, rahn pada prinsipnya merupakan suatu kegiatan hutang piutang yang murni berfungsi sosial, sehingga dalam buku fiqh mu'amalah akad ini merupakan akad tabarru atau akad derma yang tidak mewajibkan imbalan jasa.

Kedua, Pengertian Al-Qardh. Secara bahasa, Al-Qardh atau Rahn a r t i n y a gadai atau berarti "al-Subūt wa al-Dawām" yang artinya tetap dan kekal. Sebagian ulama lughat mengartikan ar-rahn dengan "alHabsu" (menahan). ${ }^{9}$

Abu Bakar Jabir al-Jazairi, mendefinisikan rahn dengan menjamin hutang dengan barang di mana hutang dimungkinkan bisa dibayar dengannya, atau dari hasil penjualannya. ${ }^{10}$

Sedangkan pengertian gadai secara istilah menurut Ahmad Azhar Basyir adalah menjadikan sesuatu benda bernilai menurut pandangan syara' sebagai tanggungan hutang, dengan adanya benda yang menjadi tanggungan itu seluruh atau sebagian hutang dapat diterima. ${ }^{11}$ Dalam adat, gadai tanah biasa dikenal dengan istilah jual gadai. Jual gadai merupakan penyerahan tanah dengan pembayaran kontan, dengan ketentuan si penjual tetap berhak atas pengembalian tanahnya dengan jalan menebusnya kembali. ${ }^{12}$

Dari beberapa definisi di atas dapat dipahami bahwa gadai adalah penahanan suatu barang atau jaminan atas hutang, jika hutang sudah dilunasi maka jaminan itu kembali pada yang punya.

Sudah menjadi tradisi bagi masyarakat pedesaan dengan menggadaikan tanah sawahnya. Hal tersebut dilakukan semata-mata karena adanya kebutuhan yang sangat mendesak dan memerlukan

Insani Press. 2001). Hal: 128

${ }^{9}$ As- Sayyid Sabiq, Fiqh as - Sunnah, (Beirut: Dār al-Fikr, t.t ) III : 187

${ }^{10}$ Abu Bakar Jabir al-Jazairi, Ensiklopedi Muslim, cet. ke - 7 ( Jakarta : Dārul Falāh, 2004), hlm. 531.

11 Ahmad Azhar Basyir, Hukum Islam Tentang Riba, Hutang Piutang dan Gadai, cet. ke-2, ( Bandung : al - Ma'arif, 1993), hlm. 50.

12 Opcit hlm. 50. 
dana secepatnya. Sedangkan proses gadai sawah tersebut dilakukan sangat sederhana, yaitu dengan datangnya si A yang akan menggadaikan tanah sawahnya kepada si B seseorang yang akan memberikan pinjaman. Masyarakat biasanya menggadaikan tanah sawahnya kepada kerabat atau famili ataupun kepada tetangganya sendiri. Dengan waktu pengembalian uang pinjaman (utang) tidak ditentukan bahkan ada yang mencapai puluhan tahun. Dan pada saat transaksi gadai itu dilaksanakan kedua belah pihak tidak menghadirkan saksi karena antara penggadai (rahin) dan penerima gadai (murtahin) sudah saling percaya, tetapi ada sebagian rahin dan murtahin yang mendaftarkannya kepada perangkat desa sebagai antisipasi jika suatu saat nanti ada salah satu pihak yang ingkar janji atau melakukan wanprestasi.

Tradisi yang ada dan berlaku di sana, setiap bentuk pinjaman apapun itu baik dengan cara gadai atau pinjaman murni tanpa ada barang jaminan, uang pinjaman yang diberikan oleh murtahin disamakan dengan nilai harga emas. Sebagai contoh si A meminjam uang Rp 3.000.000,- kepada si B, dan nilai harga emas pergramnya pada saat meminjam uang Rp 300.000,- maka uang pinjaman tersebut bernilai emas 10 gram pada waktu ia mengembalikan uang tersebut. Bentuk pinjaman yang demikian tentunya bisa merugikan salah satu pihak dan biasanya pihak yang paling merasa dirugikan adalah pihak penggadai (rahin) karena ia akan membayar hutang lebih besar dari nilai pinjaman yang diterima, selain itu terkadang tanah sawah yang dijadikan sebagai jaminan hutang dikuasai (digarap) oleh murtahin beserta hasilnya.

Pada saat rahin melakukan transaksi gadai sebenarnya ada unsur keterpaksaan karena mau tidak mau ia harus ridha dengan ketentuan yang diberikan oleh murtahin berkaitan dengan nilai pinjaman yang distandarkan dengan nilai harga emas. Sedangkan dalam bermuamalah sendiri Islam mengajarkan untuk dilakukan atas dasar suka rela tanpa mengandung unsur paksaan dan yang perlu diperhatikan adalah harus memelihara nilai-nilai keadilan jangan sampai mengambil kesempatan dalam kesempitan serta menghindarkan unsur-unsur penganiayaan dan mendholimi yang lain.

Al-Qardh adalah pinjaman yang diberikan kepada nasabah (muqtaridh) yang membutuhkan dana dan/atau uang. Oleh karena itu, nasabah Al-Qardh berkewajiban mengembalikan jumlah pokok yang diterima pada waktu yang disepakati bersama antara pihak pemberi pinjaman dengan pihak yang menerima pinjaman. Namun, biaya administrasi yang dibutuhkan akan dibebankan kepada nasabah atau peminjam. Selain itu, lembaga keuangan syariah dapat meminta jaminan 
kepada nasabah bila dianggap perlu. Jaminan dimaksud dapat berarti agunan dan/atau harta benda yang menjadi jaminan hutang. ${ }^{13}$

Nasabah Al-Qardh dimaksud, dapat memberikan tambahan (sumbangan) dengan sukarela kepada lembaga keuangan syariah selama tidak diperjanjikan dalam akad. Namun, bila pinjaman dimaksud, nasabah tidak dapat mengembalikan sebagian atau seluruh kewajibannya pada saat yang telah disepakati dan lembaga keuangan syariah telah memastikan ketidakmampuan peminjam, maka lembaga keuangan syariah dapat: Pertama, memperpanjang jangka waktu pengembalian, dan/atau Kedua, menghapus sebagian atau seluruh kewajiban peminjam.

Lain halnya, bila nasabah tidak menunjukkan keinginanya untuk mengembalikan sebagian atau seluruh kewajibannya dan bukan karena ketidakmampuannya maka lembaga keuangan syariah dapat menjatuhkan sanksi kepada nasabah. Sanksi dimaksud, dapat berupa penjualan barang jaminan. Namun, bila barang jaminan tidak mencukupi, maka harta yang lain yang dimiliki oleh nasabah diambil untuk memenuhi kewajiban secara penuh.

\section{Dasar Hukum Gadai menurut Hukum Islam (Syariah)}

Dasar hukum yang menjadi landasan Gadai Syariah adalah ayatayat Al-Qur'an, hadis Nabi Muhammad SAW dan ijma' ulama.

a) Al-Qur'an

QS. Al-Baqarah (2) ayat 283 yang digunakan sebagai dasar dalam membangun konsep gadai.

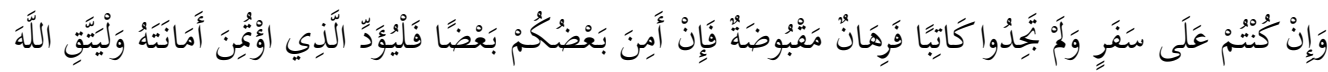

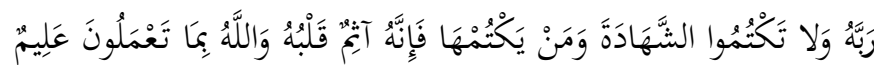

"Dan jika kamu dalam perjalanan sedang kamu tidak mendapatkan seorang penulis, maka hendaklah ada barang jaminan yang dipegang. Tetapi, jika sebagian kamu mempercayai sebagian yang lain, hendaklah yang dipercayai itu menunaikan amanatnya (hutangnya) dan hendaklah dia bertakwa kepada Allah, Tuhan-nya. Dan janganlah kamu menyembunyikan kesaksian, karena barang siapa menyembunyikannya, sungguh, hatinya kotor (berdosa). Allah Maha Mengetahui apa yang kamu kerjakan".(QS. AlBaqarah: 283)

13 Fatwa Dewan Syariah Nasional Majelis Ulama Indonesia. Himpunan Fatwa Dewan Syariah Nasional untuk Lembaga Keuangan Syariah. (Jakarta: Dewan Syariah Nasional MUI bekerja sama dengan Bank Indonesia, 2001), hlm, 105. 
b) Hadis Nabi Muhammad SAW

Dasar hukum yang kedua untuk dijadikan rujukan dalam membuat rumusan gadai syariah adalah hadis Nabi Muhammad SAW, yang antara lain diungkapkan sebagai berikut

Pertama, hadis A'isyah ra. Yang diriwayatkan oleh Imam Muslim:

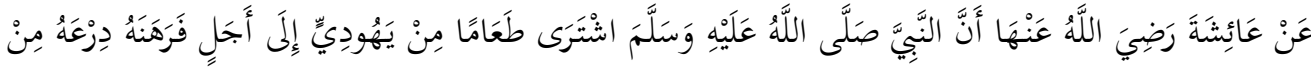

$$
\begin{aligned}
& \text { حَدِيدٍ }
\end{aligned}
$$

"Dari Aisyah RA, sesungguhnya Nabi Muhammad SAW membeli makan dari seorang Yahudi secara utang dengan menggadaikan baju besinya".14 Bukhari'

Kedua, hadis dari Abu Hurairah ra yang diriwayatkan oleh Imam Al

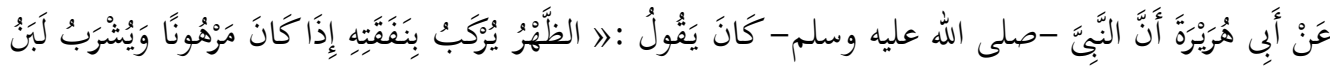

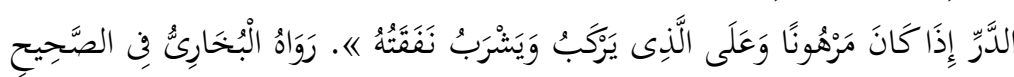

"dari Abu Hurairah, dari Nabi SAW, bahwasanya beliau bersabda: binatang tunggangan boleh ditunggangi lantara member nafaqahnya apabila ia tergadai, dan susu boleh diminum lantaran member nafaqohnya apabila ia tergadai, dan wajib orang yang menunggang dan yang meminum member nafaqohnya". (HR. Al-Bukhari)

Ketiga, hadis riwayat Abu Hurairah ra, berbunyi:

$$
\text { عن أبي هريرة قال : قال رسول الله صلى الله عليه و سلم : " لايغلق الرهن ممن رهنه له غنمه وعليه غرمه }
$$

"Barang gadai tidak boleh digelapkan dari pemilik yang menggadaikan, baginya tetap menjadi pemilik yang wajib baginya melunasi utangnya" (HR. Asy-Syafi'i dan Ad-Daruquthni)

c) Ijma' Ulama

Jumhur ulama menyepakati kebolehan status hukum gadai. Hal dimaksud berdasarkan pada kisah Nabi Muhammad SAW yang menggadaikan baju besinya untuk mendapatkan makanan dari seorang Yahudi. Para ulama juga menggambarkan indikasi dari contoh Nabi Muhammad SAW tersebut ketika beliau beralih dari yang biasanya bertransaksi kepada para sahabat yang kaya kepada seorang Yahudi, bahwa hal itu tidak lebih sebagai sikap Nabi Muhammad SAW yang tidak

14 Imam al-Bukhāri, Sahih al-Bukhāri, (Beirut: Dār al-Fikr, 1891), III : 1115, " Bab Fī Rahni Fī al-HadĪs". Hadits riwayat al-Bukhāri dari Musaddad dari ab al-Wahid dari alA'mas dari Ibrahim.

$320 \mid$ JURNAL LISAN AL-HAL 
mau memberatkan para sahabat yang biasanya enggan mengambil ganti ataupun harga yang diberikan oleh Nabi Muhammad SAW kepada mereka.

\section{Rukun dan Syarat-Syarat Gadai menurut Hukum Islam (Syariah)}

Pada umunya aspek hukum keperdataan Islam (fiqh mu'amalah) dalam hal transaksi baik dalam bentuk jual beli, sewa-menyewa, gadai maupun yang semacamnya mempersyaratkan rukun dan syarat sah termasuk dalam transaksi gadai. Demikian juga hak dan kewajiban bagi pihak-pihak yang melakukan transaksi gadai.

a) Rukun Gadai

Dalam fikih empat mazhab (fiqh al-madzahib al-arba'ah) diungkapkan rukun gadai sebagai berikut: pertama, aqid (orang yang berakad/melakukan transaksi). Aqid adalah orang yang melakukan akad yang meliputi 2 (dua) pihak, yaitu: (1) Rahin (orang yang menggadaikan barangnya), dan (2) Murtahin (orang yang berpiutang dan menerima barang gadai), atau penerima gadai. Hal dimaksud, didasari oleh shighat, yaitu ucapan berupa ijab qabul (serah-terima antara penggadai dengan penerima gadai). Untuk melaksanakan akad rahn yang memenuhi kriteria syariat Islam, sehingga akad yang dibuat oleh 2 (dua) pihak atau lebih harus memenuhi beberapa rukun dan syarat.

Kedua, ma'qud 'alaih (barang yang diakadkan) Ma'qud 'alaih meliputi 2 (dua) hal, yaitu: (1) Marhun (barang yang digadaikan) (2) Marhun bih (dain), atau hutang yang karenanya diadakan akad rahn.

b) Syarat-Syarat Gadai menurut Hukum Islam (Syariah)

Selain rukun yang harus terpenuhi dalam transaksi gadai, maka dipersyaratkan juga syarat. Syarat-syarat gadai dimaksud, terdiri atas: Pertama, shigat. Syarat shigat tidak boleh terikat dengan syarat tertentu dan waktu yang akan datang. Kecuali jika syarat itu mendukung kelancaran akad maka diperbolehkan. Kedua, pihak-pihak yang berakad. Pihak-pihak yang Berakad. Hukum Pihak-pihak yang cakap menurut hukum mempunyai pengertian bahwa pihak rahin dan marhun cakap melakukan perbuatan hukum, yang ditandai dengan aqil baliq, berakal sehat, dan mampu (cakap) melakukan akad, bukan safih (orang yang di bawah pengampuan/perwalian).

Ketiga, hutang (Marhun Bih). Hutang (marhun bih) mempunyai pengertian bahwa: (1) Hutang adalah kewajiban bagi pihak berhutang untuk membayar kepada pihak yang memberi piutang; (2) Merupakan barang yang dapat dimanfaatkan, jika tidak bermanfaat maka tidak sah; (3) Barang tersebut dapat dihitung nilai jumlahnya. Keempat, marhun . Marhun adalah harta yang dipegang oleh murtahin (penerima gadai) atau 
wakilnya, sebagai jaminan hutang. Para ulama menyepakati bahwa syarat yang berlaku pada barang gadai adalah syarat yang berlaku pada barang yang dapat diperjual belikan, yang ketentuannya adalah: (1) Agunan itu harus bernilai harta dan dapat dimanfaatkan menurut ketentuan syariat Islam; (2) Agunan itu harus dapat dijual dan nilainya seimbang dengan besarnya hutang; (3) Agunan itu harus jelas dan tertentu (harus dapat ditentukan secara spesifik); (4) Agunan itu sah milik debitur; (5) Agunan itu tidak terikat dengan hak orang lain (bukan milik orang lain, baik sebagian maupun seluruhnya); (6) Agunan itu harus harta yang utuh, tidak berada dibeberapa tempat. (7) Agunan itu dapat diserahkan dan disimpan/dikuasai (مقبوضة) kepada pihak lain, baik materinya maupun manfaatnya. ${ }^{15}$

Di samping itu, menurut Fatwa DSN-MUI No. 25/DSNMUI/III/2002 gadai syariah harus memenuhi ketentuan umum berikut: (1) Murtahin (penerima barang) mempunyai hak untuk menahan, menyimpan atau menguasai marhun (barang) sampai semua hutang rahin (yang menggadaikan barang) dilunasi. (2) Marhun dan manfaatnya tetap jadi milik rahin. Pada prinsipnya, marhun tidak boleh dimanfaatkan oleh murtahin kecuali seizin rahin, dengan tidak mengurangi nilai marhun dan pemanfaatannya itu sekadar pengganti biaya pemeliharaan dan perawatannya. (3) Pemeliharaan dan penyimpanan marhun pada dasarnya menjadi kewajiban rahin, namun dapat dilakukan juga oleh murtahin, sedangkan biaya dan pemeliharaan penyimpanan tetap menjadi kewajiban rahin. (4) Besar biaya pemeliharaan dan penyimpanan mahun tidak boleh ditentukan berdasarkan jumlah pinjaman. (5) Penjualan marhun (a) Apabila jatuh tempo, murtahin harus memperingatkan rahin untuk segera melunasi hutangnya. (b) Apabila rahin tetap tidak dapat melunasi hutangnya, maka marhun dijual paksa/dieksekusi melalui lelang sesuai syariah. (c) Hasil penjualan marhun digunakan untuk melunasi hutang, biaya pemeliharaan dan penyimpanan yang belum dibayar serta biaya penjualan. (d) Kelebihan hasil penjualan (jika ada) menjadi milik rahin dan kekurangannya menjadi kewajiban rahin. Sedangkan untuk gadai emas syariah, menurut Fatwa DSN-UI No. 26/DSN-MUI/III/2002 gadai emas syariah harus memenuhi ketentuan umum berikut: (1) Rahn emas dibolehkan berdasarkan prinsip rahn. (2) Ongkos dan biaya penyimpanan barang (marhun) ditanggung oleh penggadai (rahin). (3) Ongkos penyimpanan besarnya didasarkan pada pengeluaran yang nyatanyata diperlukan. (4) Biaya penyimpanan barang (marhun) dilakukan

15 Zainuddin Ali. Hukum Gadai Syariah. (Jakarta: Sinar Grafika. 2008), hlm. 20-22.

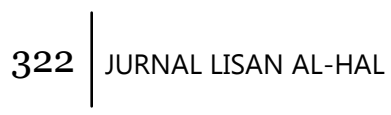


berdasarkan akad ijarah.

\section{Akad Gadai menurut Hukum Islam (Syariah)}

Pada dasarnya Gadai menurut Hukum Islam (Syariah) berjalan di atas dua akad transaksi syariah yaitu: 1) Akad Rahn. Rahn yang dimaksud adalah menahan (menyimpan) harta milik si peminjam sebagai jaminan atas pinjaman yang diterimanya, pihak yang menahan memperoleh jaminan untuk mengambil kembali seluruh atau sebagian piutangnya. 2) Akad Ijarah (sewa menyewa). Yaitu akad pemindahan hak guna atas barang dan/atau jasa melalui pembayaran upah sewa, tanpa diikuti dengan pemindahan kepemilikan atas barangnya sendiri. Akad Gadai menurut Hukum Islam (Syariah) juga harus memenuhi ketentuan atau persyaratan yang menyertai meliputi: 1) Akad tidak mengandung syarat fasik/batil seperti mutahin mensyaratkan barang jaminan dapat dimanfaatkan tanpa batas. 2) Marhun Bih (pinjaman) merupakan hak yang wajib dikembalikan kepada murtahin dan bisa dilunasi dengan barang yang digadaikan tersebut. 3) Marhun (barang yang digadaikan) bisa dijual dan nilainya seimbang dengan pinjaman, memiliki nilai, jelas ukurannya, milik sah penuh dari rahin, tidak terikat dengan hak orang lain, dan bisa diserahkan baik materi maupun manfaatnya. 4) Jumlah maksimum dana rahn dan nilai likuidasi barang yang digadaikan serta jangka waktu rahn ditetapkan dalam prosedur. 5) Rahn dibebani jasa manajemen atas barang berupa: biaya asuransi, biaya penyimpanan, biaya keamanan, dan biaya pengelolaan serta dministrasi. ${ }^{16}$

\section{Syarat-Syarat Barang Yang Digadaikan}

Imam Madzhab sepakat bahwa barang-barang yang boleh digadaikan adalah barang yang boleh diperjualbelikan oleh syara' baik barang tersebut bisa dipindahkan seperti baju besi atau barang-barang yang tidak bisa dipindahkan seperti 'Aqaar dan Ardh (tanah atau rumah).

Adapun praktek penyerahan untuk barang yang tidak bisa dipindahkan adalah dengan Takhliyah, (Pengosongan hak sementara dari pemilik tanah yang kemudian dialihkan statusnya sebagai barang gadai untuk murtahin. Hal ini bisa diserahkan secara simbolis dengan pengalihan status yang asalnya bukan barang gadai menjadi barang yang tergadaikan. ${ }^{17}$

16 Andri Soemitra. Bank dan Lembaga Keuangan Syariah. (Jakarta: Kencana Prenada Media Group. 2009), hlm. 387-388

17 Wahbah Az-Zuhaili, Mausu'ah Al-fiqhul Al-Islami Wal-Qadhaya Al-Mu'ashirah, Juz 
Walaupun demikian qaul syafiiyah dalam kitab fiqqus Sunnah bab gadai; barang yang boleh digadaikan hanya barang yang memiliki sifat "AlMaqbudhoh" (bisa digenggam), sehingga barang yang tidak bisa digenggam seperti tanah adalah tidak sah dijadikan barang jaminan/ agunan.

\section{Hukum Memanfaatkan Barang Gadai (Marhun)}

a) Memanfaatkan marhun oleh rahin (yang menggadaikan),

Terdapat dua pendapat yaitu: (1) Hukum Menurut Hanafiyah, Malikiyah, dan Hanabilah, Pihak Rahin dilarang memanfaatkan barang yang telah digadaikan. Hanya saja ulama hanafiyah membolehkan jika mendapat izin dari murtahin. Namun pendapat imam Maliki lebih ekstrim bahwa meskipun rahin mendapat izin dari murtahin tetap tidak boleh, karena hal itu akan menyebabkan akad rahn batal.

(2) Menurut Syafiiyah, Rahin boleh memanfaatkan marhun selama itu tidak merugikan dan tidak menimbulkan kemudharatan bagi pihak alMurtahin. Pendapat ini dikarenakan menurut syafiiyah kemanfaatan marhun, perkembangannya dan apa-apa yang dihasilakan oleh marhun adalah milik rahin dan statusnya tidak ikut terikat dengan utang yang ada. ${ }^{18}$

b) Memanfaatkan marhun oleh Murtahin (penerima Gadai)

Terdapat dua pendapat yaitu: (1) Menurut Ulama' Hanabilah boleh memanfaatkan jika barang yang digadaikan adalah hewan sesuai dengan kadar nafkahnya. (2) Menurut Syafiiyah, Malikiyah dan Hanafiyah, murtahin tidak boleh memanfaatkan Marhun, baik berupa hewan maupun yang lain.

Sebagian ulama' hanafiyah membolehkan jika mendapatkan izin dari pihak rahin, dan pemberian izin tersebut tidak disebutmenjadi syarat sewaktu akad. Namun demikian sebagian ulama' hanafiyah masih juga melarang betapapun mendapat izin karena hal itu termasuk riba atau syubhat riba. Izin dari rahin tetap tidak bisa melegalkan riba.

Ulama' Malikiyah memang tidak membenarkan pemanfaatan barang gadai akan tetapi hal ini menjadi boleh jika pemanfaatan tersebut disyaratkan dalam akad jual beli dan batas waktunya ditentukan. Pemanfaatan ini boleh jika secara Cuma-Cuma, atau sebagai bagian/cicilan dari pembayaran hutang, yang sisanya nantinya akan segera dilunasi.

5, (Bairut: Dar Al-Fikr), hlm. 97-105 bab syarat-syarat harta yang boleh digadaikan.

18 Wahbah Az-Zuhaili, Mausu'ah Al-fiqhul Al-Islami Wal-Qadhaya Al-Mu'ashirah, Juz

5, (Bairut: Dar Al-Fikr, tt), hlm. 143-145.

324 JURNAL LISAN AL-HAL 
Ulama' Syafiiyah, membolehkan pemanfaatan barang gadai oleh murtahin jika kemanfaatan barang diketahui, sementara gadai disyaratkan dalam akad jual beli (tidak secara tunai), maka sah/boleh, karena hal itu suatu bentuk penggabungan antara akad jual beli dan akad sewa dalam satu transaksi. Misalnya si A berkata pada si B, "Saya menjual kudaku ini kepadamu seharga seratus dengan syarat kamu menggadaikan rumahmu dengan Utang (Al-marhun Bih) adalah harga kuda tersebut yaitu seratus dan kemanfaatan rumah tersebut untukku selama satu tahun". dengan demikian sebagaian kuda tersebut statusnya menjadi mabi'(yang dijual) sedangkan sebagiannnya lagi biaya sewa pengganti pemanfaatan rumah. ${ }^{19}$

Dalam kitab Bughyatu Al Musytarsyidin disebutkan bahwa bentuk jual beli dengan terjadinya kesepakatan antara penjual dan pembeli, dengan persyaratan penjual menjual barang kepada pembeli, dan dalam waktu tertentu pembeli menjual kembali kepada penjual dengan harga yang telah disepakati sebelum terjadinya akad, hal ini disebut sebagai Bay'ul Uhdah. ${ }^{20}$

Bentuk daripada jual beli ini adalah seperti seorang penjual barang menyampaikan kepada pembelinya, " nanti setelah dua bulan, saya akan membeli barang ini lagi kepadamu, dengan harga yang sama, atau ia juga mengatakan dengan harga yang disesuaikan kurs emas. Akan tetapi pembeli tidak wajib menyerahkan barang tersebut selama penjual tidak memenuhi persyaratannya itu, Akad jual beli uhdah terjadi setelah terjadinya kesepakatan diatas sehingga ketika terjadinya akad tidak terdapat persyaratan yang diucapkan ketika berlangsungnya akad.

Menurut pengarang bughiyah, bahwa bay'ul uhdah ini hukumnya syah dan tidak makruh, walaupun ada yang mengatakan makruh, hal ini bukan berarti bayul uhdahnya dilarang tetapi karena ia tidak memenuhi janjinya untuk mengembalikan harga yang telah ditentukan sebelum terjadinya akad tersebut atau bahkan persyaratannya berkaitan dengan hal-hal yang makruh atau berkitan dengan riba, sehingga menyebabkan akad jual beli uhdah menjadi makruh atau dilarang.

Sebagaimana prinsip dalam jual beli yaitu kesepekatan atau saling rela. Begitupun dalam jual beli uhdah ini, sehingga ketika pembeli uhdah mengelola tanah dan memaninnya tanpa adanya izin dari penjualnya, maka hal itu dikatakan sebagai barang ghasab, dan penjual berhak

19 Wahbah Az-Zuhaili, Al-fiqhul Al-Islami Wal-Qadhaya Al-Mu'ashirah, Juz 5, (Bairut: Dar Al-Fikr, tt), hlm. 146-149. 218-220

20 Sayyid Abdur Rahman, Bughyatu Al Musytarsyidin, (Bairut: Dar-Alfikr, tt), hlm. 
mencabut paksa dan wajib dikembalikan sebagaimana semula. Walaupun demikian menurut peneliti praktik helah (rekayasa) di atas bertentangan dengan prinsip-prinsip dan hikmatuttasyri'dari hukum gadai maupun jual beli.

\section{Simpulan}

Setelah menganalisis dari beberapa pendapat imam madzhab diatas, dapat dirumuskan tentang solusi atas permasalahan gadai tanah yang berkembang di masyarakat. Dengan solusi tersebut diharapkan nantinya praktek gadai yang telah menjadi tradisi masyarakat akan sesuai dengan syariat islam dan tidak merugikan salah satu pihak dari pelaku gadai.

Ada beberapa hal yang dapat dijadikan sebagai solusi atas permasalahan tersebut yaitu: Pertama, Dengan cara melakukan kerja sama dengan pemerintah daerah untuk mensosialisasikan dan melaksanakan penyuluhan kepada masyarakat tentang gadai yang sesuai dengan hukum Islam, Hukum Positif dan hukum adat, dengan tetap menempatkan hukum islam sebagai hukum tertinggi yang akan dipraktekan pada masayarakat dan hukum positif dan hukum adat sebagai pelengkapnya.

Kedua, Dalam traksaksi gadai disebutkan sebagai akad jual, dengan memberikan kemudahan kepada kedua belah pihak, atau bahkan ketika rahin tidak bisa menyerahkan pinjaman hutangnya ketika jatuh tempo, maka diperkenankan untuk menjual tanahnya tersebut kepada murtahin atau lainnya dengan catatan manakala ada kelebihan harta ketika dibayarkan hutangnya maka harus diserahkan kepada rahin. Seperti contoh tanah jaminannya terjual 100 juta, sementara hutangnya hanya 40 juta, maka sisa uangnya sebesar 60 juta diserahkan kepada rahin/ pemilik tanah.

Ketiga, Pemerintah tidak hanya mensosialisasikan terkait masalah gadai akan tetapi juga harus dikawal dan ditindaklanjuti terkait masalah gadai yang berkembang di masyarakat. Misalnya adanya kewajiban melaporkan bagi pelaku gadai ke pemerintah desa. Kemudian perangkat desa bisa menjelaskan dan mengakad kedua belah pihak sebagaimana akad gadai yang sesuai dengan syariat.

Keempat, merubah akad gadai dengan akad jual beli kembali dengan tanpa menentukan batas waktu ketika akad, akan tetapi kedua pelaku gadai telah memahami bahwa suatu saat bisa dibeli kembali oleh pihak pemilik sawah, dan kesepakatan ini dilakukan sebelum akad. Dalam hukum islam dikenal dengan istilah Bay'ul Uhdah atau Bay'ul Wafa'. 


\section{DAFTAR PUSTAKA}

al-Bukhāri, Imam., Sahih al-Bukhāri, Beirut: Dār al-Fikr, 1891.

Ali, Zainuddin, Hukum Gadai Syariah. Jakarta: Sinar Grafika. 2008.

Al-Zarqo', TT, Musthofa, Al-Madkhol Al-Fiqh Al-'Am, Bairut; Dar Al-Fikr.

Az-Zuhaili, Wahbah ,tt, Al-fiqhul Al-Islami Wal-Qadhaya Al-Mu'ashirah, Juz 5, Bairut: Dar Al-Fikr.

, tt, Mausu'ah Al-fiqhul Al-Islami Wal-Qadhaya Al-Mu'ashirah, Juz 5, Bairut: Dar Al-Fikr.

Basyir, Ahmad Azhar, Hukum Islam Tentang Riba, Hutang Piutang dan Gadai, cet. ke-2, Bandung : al - Ma'arif. 1993.

Depag RI. Al-Qur'an Dan Terjemahan. Jakarta: Yayasan Penyelenggara Penerjemah Dan Penarsir Al-Qur'an. 1984.

Fatwa Dewan Syariah Nasional Majelis Ulama Indonesia. Himpunan Fatwa Dewan Syariah Nasional untuk Lembaga Keuangan Syariah. Jakarta: Dewan Syariah Nasional MUI bekerja sama dengan Bank Indonesia. 2001.

Jabir al-Jazairi, Abu Bakar, Ensiklopedi Muslim, cet. ke - 7, Jakarta : Dārul Falāh. 2004.

Asas-asas Hukum Muamalah (Hukum Perdata Islam), ed. Revisi, Yogyakarta: UII Press. 2000.

Sabiq, As- Sayyid. tt, Fiqh as - Sunnah, Beirut: Dār al-Fikr.

Sayyid Abdur Rahman, tt, Bughyatu Al Musytarsyidin, Bairut: Dar-Alfikr.

Soemitra, Andri, Bank dan Lembaga Keuangan Syariah. Jakarta: Kencana Prenada Media Group. 2009.

Solikhul Hadi, Muhammad, Pegadaian Syariah, Jakarta: Salemba Diniyah, 2003.

Syafi'i Antonio, Muhammad, Bank Syariah dai Teori ke Praktik. Jakarta: Gema Insani Press. 2001.

Usman, Suparman, Hukum Islam (Asas-asas Dan Pengantar Studi Hukum Islam Dalam, Tata Hukum Indonesia), Jakarta: Gaya Media Pratama. 2001. 
"'Reformulasi Pemanfaatan Barang Gadai"

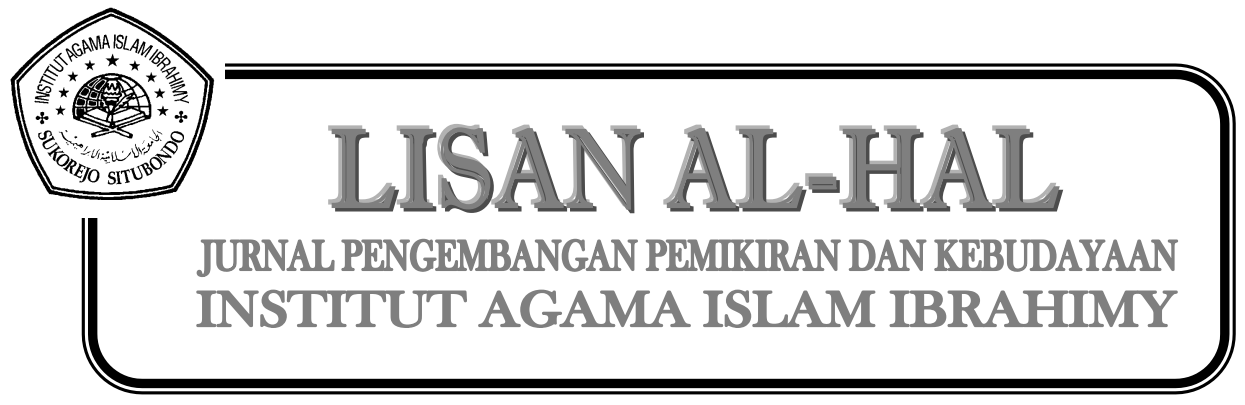

$328 \mid$ JURNAL LISAN AL-HAL 